\title{
Effects of Rosiglitazone on Inflammation in Otsuka Long-Evans Tokushima Fatty Rats (Korean Diabetes J 2010;34:191-9)
}

\author{
Eun Sook Kim \\ Department of Internal Medicine, Ulsan University Hospital, Ulsan University College of Medicine, Ulsan, Korea
}

Thank you for your comments regarding our manuscript entitled "Effects of rosiglitazone on inflammation in Otsuka LongEvans Tokushima Fatty rats," which was published in Korean Diabetes J 2010;34:191-9. The authors appreciate your constructive and helpful comments. We have responded to the questions below.

Thiazolidinediones (TZD), including rosiglitazone, are highaffinity ligands for peroxisome proliferator-activated receptorsgamma (PPAR- $\gamma$ ) and are used as insulin-sensitizing drugs [1]. PPAR- $\gamma$ is predominantly expressed in adipose tissue, whereas the improvement in insulin sensitivity after TZD treatment occurs mainly in skeletal muscle where PPAR- $\gamma$ expression is relatively low [2]. Therefore, it has been suggested that TZD improves peripheral insulin action by modulating communication signals, such as adiponectin [3], leptin [4] and tumor necrosis factor-alpha (TNF- $\alpha$ ) [5], between fat and muscle. Another explanation is that TZD improves insulin sensitivity by promoting the redistribution of triglycerides from the liver and muscle to the adipose tissue [6,7]. Many studies have reported that PPAR- $\gamma$ agonists result in lipid storage coupled with the reduced release of free fatty acids (FFA) into the circulation and also increase subcutaneous adiposity but have no effect on visceral fat mass [8].

In the studies on Otsuka Long-Evans Tokushima fatty (OLETF) rats, PPAR- $\alpha$ activators, including bezafibrate and rosiglitazone, greatly suppressed the expression of proinflam- matory cytokines such as TNF- $\alpha$, interleukin (IL)- $1 \beta$ and IL6 , and $\alpha$-smooth muscle actin (SMA) in the pancreas $[7,8]$. In our study, we investigated the effects of the insulin-sensitizing anti-diabetic agent rosiglitazone on the progression of skeletal muscle inflammation in OLETF rats. We found that rosiglitazone decreased the concentrations of glucose, insulin and inflammatory cytokines in the sera of OLETF rats. Rosiglitazone also inhibited mRNA expression of inflammatory cytokines in skeletal muscle by blocking the NF- $\mathrm{B}$ pathway. Therefore, our findings suggest that rosiglitazone may improve insulin sensitivity with its anti-inflammatory activity in the skeletal muscle of diabetic rats.

Our results concur with the findings of previous studies that PPAR- $\gamma$ agonists can improve inflammation in peripheral tissues (including the muscle and pancreas) via the inhibition of inflammatory signaling pathways $[9,10]$. Recently, TZD was discovered to have anti-inflammatory effects, and its potential was reevaluated for treating diabetes. Several studies have reported that TZD including rosiglitazone decreases serum levels of inflammatory makers TNF- $\alpha$, IL-6, C-reactive protein (CRP), and FFAs in an experimental model of induced type 2 diabetes in high-fat-diet albino rats [11,12]. In our study, FFA levels were lower in the OLETF group compared to the LETO group at the 40th week (Fig. 1). In contrast, we observed no decrease in FFA levels in the group treated with rosiglitazone. We still do not know why rosiglitazone did not decrease se-
Corresponding author: Eun Sook Kim

Department of Internal Medicine, Ulsan University Hospital, Ulsan

University College of Medicine, 290-3 Junha-dong, Dong-gu, Ulsan 682-714, Korea

E-mail: es10@unitel.co.kr
This is an Open Access article distributed under the terms of the Creative Commons Attribution Non-Commercial License (http://creativecommons.org/licenses/by-nc/3.0/) which permits unrestricted non-commercial use, distribution, and reproduction in any medium, provided the original work is properly cited. 


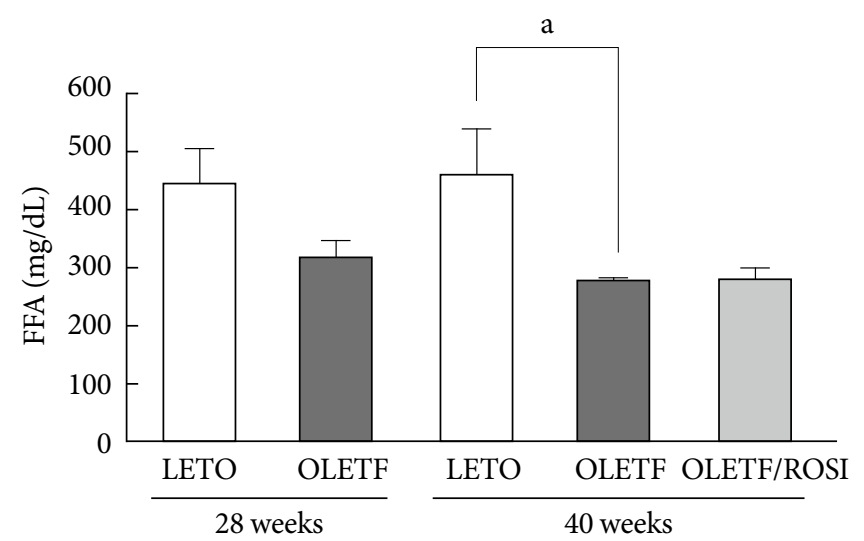

Fig. 1. Changes in concentration of serological markers in LETO and OLETF rats. Free fatty acid levels in the sera of LETO or OLETF rats were measured by colorimetric and enzymatic assay at 28 and 40 weeks. Values are represented as mean \pm standard deviation. ${ }^{\text {a }} P<0.05$ as compared to each group. ROSI, rosiglitazone; FFA, free fatty acid (From Lee JW, et al. Korean Diabetes J 2010;34:191-9).

rum FFA concentrations in the stage of insulin resistance of OLETF rats.

Furthermore, the anti-inflammatory effects of rosiglitazone that block the inflammatory pathway in skeletal muscle inflammation in diabetic and insulin-resistant patients without excessive FFA influx into the skeletal muscle are not clear. Due to the link between insulin resistance and inflammatory processes, we suggest that therapeutic strategies to limit inflammation and reduce levels of inflammatory markers may be a promising tool in reducing symptoms in such patients $[13,14]$.

\section{REFERENCES}

1. Lowell BB. PPARgamma: an essential regulator of adipogenesis and modulator of fat cell function. Cell 1999;99:239-42.

2. Auboeuf D, Rieusset J, Fajas L, Vallier P, Frering V, Riou JP, Staels B, Auwerx J, Laville M, Vidal H. Tissue distribution and quantification of the expression of mRNAs of peroxisome proliferator-activated receptors and liver X receptor- $\alpha$ in humans: no alteration in adipose tissue of obese and NIDDM patients. Diabetes 1997;46:1319-27.

3. Yamauchi T, Kamon J, Waki H, Terauchi Y, Kubota N, Hara K, Mori Y, Ide T, Murakami K, Tsuboyama-Kasaoka N, Ezaki O, Akanuma Y, Gavrilova O, Vinson C, Reitman ML, Kagechika H, Shudo K, Yoda M, Nakano Y, Tobe K, Nagai R, Kimura S, Tomita M, Froguel P, Kadowaki T. The fat-derived hormone adiponectin reverses insulin resistance associated with both lipoatrophy and obesity. Nat Med 2001;7:941-6.

4. Shimomura I, Hammer RE, Ikemoto S, Brown MS, Goldstein JL. Leptin reverses insulin resistance and diabetes mellitus in mice with congenital lipodystrophy. Nature 1999;401:73-6.

5. Hotamisligil GS, Shargill NS, Spiegelman BM. Adipose expression of tumor necrosis factor-alpha: direct role in obesity-linked insulin resistance. Science 1993;259:87-91.

6. Mayerson AB, Hundal RS, Dufour S, Lebon V, Befroy D, Cline GW, Enocksson S, Inzucchi SE, Shulman GI, Petersen KF. The effects of rosiglitazone on insulin sensitivity, lipolysis and hepatic and skeletal muscle triglyceride content in patients with type 2 diabetes. Diabetes 2002;51:797-802.

7. Jia D, Otsuki M. Bezafibrate, a peroxisome proliferator-activated receptor (PPAR)-alpha activator, prevents pancreatic degeneration in obese and diabetic rats. Pancreas 2003;26:286-91.

8. Choi KC, Ryu OH, Lee KW, Kim HY, Seo JA, Kim SG, Kim NH, Choi DS, Baik SH, Choi KM. Effect of PPAR-alpha and -gamma agonist on the expression of visfatin, adiponectin, and TNF-alpha in visceral fat of OLETF rats. Biochem Biophys Res Commun 2005;336: 747-53.

9. Mohanty P, Aljada A, Ghanim H, Hofmeyer D, Tripathy D, Syed T, Al-Haddad W, Dhindsa S, Dandona P. Evidence for a potent antiinflammatory effect of rosiglitazone. J Clin Endocrinol Metab 2004;89:2728-35.

10. Remels AH, Langen RC, Gosker HR, Russell AP, Spaapen F, Voncken JW, Schrauwen P, Schols AM. PPARgamma inhibits NF-kappaB-dependent transcriptional activation in skeletal muscle. Am J Physiol Endocrinol Metab 2009;297:E174-83.

11. Garg R, Tripathy D, Dandona P. Insulin resistance as a proinflammatory state: mechanisms, mediators, and therapeutic interventions. Curr Drug Targets 2003;4:487-92.

12. Abdin AA, Baalash AA, Hamooda HE. Effects of rosiglitazone and aspirin on experimental model of induced type 2 diabetes in rats: focus on insulin resistance and inflammatory markers. J Diabetes Complications 2010;24:168-78.

13. Marx N, Froehlich J, Siam L, Ittner J, Wierse G, Schmidt A, Scharnagl H, Hombach V, Koenig W. Antidiabetic PPAR gamma-activator rosiglitazone reduces MMP-9 serum levels in type 2 diabetic patients with coronary artery disease. Arterioscler Thromb Vasc Biol 2003;23:283-8.

14. Kim HJ, Jung TW, Kang ES, Kim DJ, Ahn CW, Lee KW, Lee HC, Cha BS. Depot-specific regulation of perilipin by rosiglitazone in a diabetic animal model. Metabolism 2007;56:676-85. 